rising all around in the scene and will surely mark progress in the future. He selects only one example from the Eastern Alpes-the great problem of the "Window of the Hohe Tauern". This is seen from the point of view of the West Alpine geologists, and it is regrettable that Prof. Bailey does not take into consideration the most recent papers of a line of young geologists who have more or less got rid of the far-reaching theory of nappes. To expose the structures of the folded ranges of the Provence was relatively easy, as they appear like embryos compared with Alpine tectonics and thus offer a good training school for higher problems.

The story of a visit of the French Geological Society to the Northern Pyrenees affects us rather dramatically. A thorough change of the interpretation of these mountain ranges took place at this session. For them the theory of nappes of Alpine scale was abolished, and a 'decollement'a shearing off-of the Mesozoic and Tertiary strata was put in its place.

The struggle of conceptions of significant geological problems has found in the author its most trustworthy historian, and surely it will inspire its disciples with profound respect for the generations of explorers whose names are intimately connected with the progress of geology. F. X. SchafFER.

\section{Peter Porcupine: a Study of William Cobbett,} 1762-1835

By Marjorie Bowen. Pp. xii +312 . (London, New York and Toronto : Longmans, Green and Co., Ltd., 1935.) 10s. 6d. net.

Miss MarJorte Bowen has chosen a most interesting historical character living through modern times (1762-1835). Her portraiture of Cobbett as a public figure follows rather elosely a contemporary sketch quoted by her: "strong sense, masculine English, extravagant prejudice, political economy, currency radicalism, universal invective, all jumbled together ! personally a homely, independent, vigorous farmer".

Miss Bowen's own opinion of reform is a shock to us: "that unchanging human nature creates the same conditions about it in whatever circumstances and in whatever period it is placed" (p. 234). Her historical judgments are not always impartial. She refers to "the incompetent Rockingham, the honest North, the voluble and showy Fox", and again - "however mediocre or mistaken might be his [Pitt the younger's] motives; he was a master of the unanswerable, well graced platitude".

The background of the book is the growth and unfolding of Cobbett's character, and the scene is generally rural and domestic. Much of it is straight. forward narrative, but some psychological treatment is used, in regard to Cobbett's relations with Caroline of Brunswick, his influence on his children, his weakness for running away from danger and the unusual intellectual results of his upbringing and selfeducation.

Miss Bowen laments the decision of Cobbett to divide his strength and interests between an establishment in the country-the happy scene of his youth and the source of his inspiration, social standing and robust health-and his absorbing eareer as editor, journalist and political writer. She brings home to us his talent for popular journalism with which he laboured to stem the rising flood of pauperism, attacked what he felt to be abuses and made himself "a leader of the working elasses and the mouthpiece of the poorest people". She shows us something of Cobbett's feeling for Nature as when he wrote thus of Long Island :

"No daisies, no primroses, no cowslips, no bluebells, no daffodils, which, as if it were not enough for them to charm the sight and smell, must have names too to delight the ear."

\section{Dictionary of Organic Compounds}

Edited by Prof. I. M. Heilbron and H. M. Bunbury. Vol. 2 : Eccaine-Myrtillin Chloride. Pp. xiii +846 . (London : Eyre and Spottiswoode (Publishers), Ltd., 1936.) $£ 66 s$. net; 3 vols., $£ 15$ l5s. net.

THE second volume of this important work follows the general plan already described in Nature (November 17, 1934, p. 751). The range of the selected compounds has been extended, particularly in the direction of biochemistry, and somewhat more space has been allocated to the data and literature references : consequently, the second volume exceeds the first by some 140 pages. The literature has been surveyed up to the end of 1934, and in some instances the references extend into 1935. This volume is particularly useful, since it includes the entries under "methyl" (229 pp.) and "hydroxy" (133 pp.); these, together with "iso" (70 pp.) and "ethyl" (40 pp.), constitute, in fact, slightly more than half the volume.

Despite its wide scope, the reader will not necessarily find all his familiar friends between its covers (the reviewer misses hydroxymethylenecamphor and menthoxyacetic acid, for example), for that would be an unreasonable expectation in a work which is essentially selective. Occasionally there are noticeable omissions from the entries : for example, the latest references for 1-hydroxy-2-hydrindamine (1893) and menthol (1911) are much out of date. No work of this scope and character, however, could hope to emerge unscathed from criticism of its fine detail.

Prof. Heilbron and his collaborators are to be congratulated on having maintained in their second volume the high standard which they set up in their first. The appearance of the concluding volume will enable organic chemists and biochemists to turn to this work as R. L. Stevenson turned to his beloved maps, with the reflection: "This, of all books, is the least wearisome to read and the richest in matter". 